CZU 346.546

DOI: https://doi.org/10.52388/2345-1971.2021.1.08

\title{
GENERALITIES ON LEGAL REGULATION OF CARTEL AGREEMENTS
}

\author{
Dumitrita BOLOGAN \\ Doctor of Law, lawjer, Program manager, Foundation „Terre des hommes”, \\ Chisinau, Republic of Moldova \\ e-mail:dumitritabologan@yahoo.com \\ https://orcid.org/0000-0002-9799-4691
}

This article provides an overview of the evolution of competition and competition law, both in the Republic of Moldova and in some European and US countries. Also, the paper crystallizes the conceptual approaches on cartels and offers an analysis of the doctrine of the Republic of Moldova, Romania, Russia, France, Germany, USA, Great Britain regarding cartel agreements. Following the analysis carried out in this paper, it was observed that the contribution of foreign academics in the field of defining and classifying cartel agreements is substantial, and the jurisprudence of the European Commission and the European Court of Justice has served as a source of inspiration and progress for the academic environment, as well as for the development of competition on the market. Although in the Republic of Moldova there is limited research in the field of cartel agreements, it is gratifying that the legislation is harmonized with European directives, and the doctrine is developed starting from the most important international research in the field of protection of competition.

Keywords: competition, cartel, agreement, law, policies, market

\section{GENERALITĂȚI CU PRIVIRE LA REGLEMENTAREA JURIDICĂA ÎNTTELEGERILOR DE CARTEL}

Acest articol oferă o privire de ansamblu asupra evoluţiei concurenţei şi a legislaţiei concurenţiale, atât în Republica Moldova, cât şi unele state europene şi SUA. De asemenea, lucrarea cristalizează abordările conceptuale asupra cartelurilor și oferă o analiză a doctrinei Republicii Moldova, a României, Rusiei, Franţei, Germaniei, SUA, Marii Britanii referitoare la înţelegerile de tip cartel. În urma analizei efectuate în această lucrare, s-a observat că aportul doctrinarilor străini în domeniul definirii și clasificării înțelegerilor de tip cartel este unul substanţial, iar jurisprudenţa Comisiei Europene şi a Curţii Europene de Justiţie au servit în calitate de sursă de inspirație şi progres, atât pentru mediul academic, cât şi pentru dezvoltarea concurenţei pe piaţă. Deși în Republica Moldova se pot atesta cercetări limitate în domeniul înțelegerilor de tip cartel, este îmbucurător faptul că legislația este armonizată directivelor europene, iar doctrina se dezvoltă pornind de la cele mai importante cercetări internaționale din domeniul protecției concurenței.

Cuvinte-cheie: concurență, cartel, înțelegere, lege, politici, piață.

\section{GÉNÉRALITÉS SUR LA RÉGLEMENTATION JURIDIQUE DES ACCORDS DE CARTEL}

Cet article donne un aperçu de l'évolution de la concurrence, tant en République de Moldova que dans certains pays européens et aux États-Unis. Aussi, l'article cristallise les approches conceptuelles sur les cartels et propose une analyse de la doctrine de la République de Moldova, de la Roumanie, de la Russie, de la France, de l'Allemagne, des États-Unis, de la Grande-Bretagne concernant les accords de cartel. Suite à l'analyse effectuée dans cet article, il a été observé que la contribution des doctrinaires étrangers dans le domaine de la définition et de la classification des ententes est importante, et la jurisprudence de la Commission européenne et de la Cour de justice européenne a servi de source d'inspiration. et le progrès de l'environnement académique, ainsi que pour le développement de la concurrence sur le marché. Bien qu'en République de Moldova, il puisse y avoir moins de recherches dans 
le domaine des ententes, il est encourageant de constater que la législation est harmonisée avec les directives européennes et que la doctrine se développe à partir des recherches internationales les plus importantes dans le domaine de la protection de la concurrence.

Mots-clés : concurrence, cartel, accord, droit, politiques, marché.

\section{ОБЩИЕ ПОЛОЖЕНИЯ О ПРАВОВОМ РЕГУЛИРОВАНИИ КАРТЕЛЬНЫХ СОГЛАШЕНИЙ}

В данной статье представлен обзор развития конкуренции как в Республике Молдова, так и в некоторых европейских странах и США. Также в статье сформулированы концептуальные подходы к картелям и дан анализ доктрины Республики Молдова, Румынии, России, Франиии, Германии, США, Великобритании относительно картельных соглатений. В результате проведенного анализа, было отмечено, что вклад иностранных доктринеров в области определения и классификации картельных соглатений является значительным, а юриспруденция Европейской комиссии и Европейского Суда послужила источником вдохновения и прогресса как для академической среды, так и для развития конкуренции на рынке. Несмотря на то, что в Республике Молдова проводится меньше исследований в области картельных соглашений, отрадно, что законодательство гармонизировано с европейскими директивами, а доктрина разработана на основе наиболее важных международных исследований в области защиты конкуренции.

Ключевые слова: конкуренция, картель, соглашение, закон, политика, рынок.

\section{Introduction}

«Our customers are our enemies» is probably the most famous quote about a cartel agreement made by a member of the international lysine cartel that operated between 1992 and 1995. Competition is the quintessence of the market economy. It means the possibility to choose from several alternatives of products or services offered. Where there is competition, a more efficient allocation of resources is achieved, as the producer constantly monitors the relationship between them and costs. One of the most severe limitation of competition represents cartel agreements - agreement between competitors with the intention of hindering or restricting competition or creating false competition. In the Republic of Moldova there are substantial gaps in the academic analysis of cartel agreements. Although the previous law in force on the protection of competition no. 1103 of 30.06.2000 regulated, in a somewhat rudimentary way, the cartel agreements between the economic agents, there are, practically, no studies or scientific analyzes to explain or interpret the legal norms.

\section{Doctrine on cartel agreements in the Republic of Moldova}

Only a few authors, such as Roşca N., Baieş S. and Volcinschi V., Cojocari E., Mărgineanu G., Rusu V., Focşa G. tangentially referred to anti-competitive practices in monographs/studies/law textbooks or business/economic or commercial law courses. The authors Rusu I. and Balan A., in a Comparative Study of Competition Policy very succinctly describe the European Union competition law, analyse and compare the existing law on competition with the provisions of Community law at that time, highlighting some gaps, and proposing certain recommendations.

Prof. E. Cojocari, analyses in her economic law paper the provisions of the law on competition protection regarding cartel agreements, categorizing as null those that increase, reduce or maintain prices, divide markets or create barriers to exit, limit access or remove economic agents from the market.

Only in 2014, lecture notes in competition law were developed, one of the first attempts in this field, but which presents a general ap- 
proach to the competition law sphere. Also in 2014, a Ms. Bulmaga O. drafted her doctoral thesis, which presents an innovative comparative study of organizational and legal measures regarding entities that carry out anti-competitive practices in the Republic of Moldova. In this thesis, referring to the anti-competitive agreements, the author uses the notion of «agreement», grounding this choice on the analysis of French and Romanian doctrine. The author investigates in Chapter I the relevant market, as well as the legal nature of the entity carrying out anti-competitive practices, and dedicates Chapter III to cartel agreements, especially to their types - classified according to their character - vertical and horizontal, but also according to other criteria.

In the framework of an European Union support project implemented in the Republic of Moldova, the experts Stuart E. and Mateus A. conducted in 2010, a study aimed at assessing the process of harmonization of the legislation of the Republic of Moldova with European Union standards in the field of competition, in order to provide practical support and expertise in the process of legislative harmonization. However, the paper does not address the cartel agreements from an academic perspective, but rather provides an overview of the Moldova's competition law and policy, a strategic assessment and key recommendations for the further, medium-term development of this sector, from a legal, economic and institutional point of view.

For these reasons, we have decided to examine in this paper the scientific research that has been carried out in other states, including Romania, Russia, in some states of the European Union, as well as in the USA, to understand if there is a uniform practice in tabulating cartels.

\section{Terminological aspects on cartel agreement in the Romanian doctrine}

Referring to cartels, some Romanian academics use the term «agreement», which also appears in the Romanian law no. 21 on competition. Irinescu L., together with other authors, Prescure T. and Gheorghiu G., defines «agreement» as any agreement between two or more economic agents (enterprises), expressed or not in writing - regardless of the form, title or nature, the act or clause containing it - tacit, explicit or implicit, public or occult, in order to coordinate competitive behaviour. Horizontal agreements are those agreements or concerted practices which are concluded between two or more undertakings operating at the same market level (producers). It encompasses both real and potential competition, represented by economic operators that can enter the market with a minimum investment, becoming real competitors. We consider that this notion is scarcely used in the literature, most academics adhere to the term «cartel», defining it as a specific oligopoly in which companies not only interact, but enter into a process of explicit cooperation, constituting an agreement - most often, secret - which aims to maximize profit at its level, divided between participants according to various criteria agreed a priori.

Professor Whish R., one of the most remarkable representatives of the British school, in the sixth edition of his book - Competition Law, widely used in Western academic circles, divides the horizontal agreements between undertakings to fix prices, divide markets, restrict production and determine the potential outcome of tenders, in:

- cartels;

- oligopoly, tacit collusion and collective dominance;

- cooperation agreements.

\section{British and European Union considerations on terminology related to cartel agreements}

Prof. Ezrachi A., in his research on European Union competition law, summarizes 450 cases of the European Court of Justice, the Civil Service Tribunal and the European Com- 
mission, most of which relate to cartels. The academic defines the cartels exclusively on the basis of the decisions of the above-mentioned European institutions. According to Stephan A. - cartels are universally the most serious infringements of competition law. The purpose of complying with the rules on cartel agreements is to ensure both a limitation and a repression of anti-competitive practices. But the problem in this area is that fines cannot prevail over illegal cartel profits, which are usually applied years after the infringement has taken place.

Connor J., collected evidence of the operation of cartels in 279 markets between 1888 and 2005. These include at least 57 which were legally active and over one hundred which were international members. The UK Trade Council studied 125 cartels active in the UK before World War II. Many of these were international cartels, covering a wide range of industries, including electrical machinery, chemicals, coal and steel, textiles, paper, glass and non-ferrous metals. Symeonidis G. found that in the 1950s, in the UK, 36 per cent of industries reported themselves as having secret agreements; and 26 percent independently reported some form of coordination.

Some British authors note that the interest in this field derived mainly from economic disciplines, based on the work of Bishop S., Clarke R. and Morgan E., Estrin S. and Holmes P., Motta M..

In Germany, we can see that since the 1960s, monographs on Kartellrecht (antitrust or cartel law) have appeared in which the scope of German cartel law is analyzed, American doctrine is studied comparatively with the European Union legislation. The authors discuss the principle of extraterritoriality of transactions and the specifics of the types of agreements and restrictive practices, as well as the application of German law on cartels to such extraterritorial conduct. The German competition authority is called the Federal Cartel Office, whose main task is to implement the 1958 Law Against Restrictions on Competition. Moreover, according to Fiebig A., due to the fact that there is no unanimously accepted definition of what competition means, the legal provisions designed to protect it are very vague.

Tschierschky S., the editor of a cartel magazine in Germany and a former cartel initiator himself, differentiates between the desire of companies to form cartels (motivation), industry conditions (structure), their ability to do so (competence), but also the existence of "practical and concrete cartel policies that have led to the discovery of the numerous ways to face these difficulties in one way or another". He emphasized "psychological" or "ethnological desire" and "the personal moment." The sustainability of the cartel depends on the ability of members to look at customers, not to ignore them, and the ability to reduce prices, sometimes to ensure greater long-term profitability. In fact, prices for coal, iron and steel in Germany fell from British domestic prices after the formation of cartels in the early 20th century. According to Peters L., the German cartel - the Rhenisch-Westphalia coal union, formed in 1893, which employed more than five hundred people, and which consisted of more than 67 firms in 1912, was an independent company with its own headquarters and set about 1400 different prices for different types of coal.

After analyzing some representatives of the French doctrine, which operate with the notion of "agreement", comprising agreements, concerted practices and decisions of business associations, we can emphasize that this notion does not appear in the legislation governing competition, but it is used by competition authorities, courts and doctrine. The author Fallon M., defines, for example, the "agreement" as any formal or informal agreement between companies, achieved through the conscious and deliberate alignment of them to certain practices, which are pursued or which have the effect of achieving competition. Bulma- 
ga O., in her doctoral thesis agrees with this opinion. However, it should be noted that the term "cartel" is used in the French literature as a synonym for the notion of "agreement" and indicates a more sophisticated form of horizontal cooperation between independent undertakings, in order to increase their market power.

According to the European Commission, agreements between competing undertakings aimed at fixing prices or sharing the market so that everyone can secure a monopoly position can distort competition rules. Anti-competitive agreements may be public or secret (e.g. cartels), concluded in writing or may be less formal (as "agreements between companies" or as decisions or regulations of professional associations). The companies that are part of the cartels are not exposed to the competitive pressure that forces economic operators to launch new products and offer consumers a better quality offer at competitive prices. As a result, consumers will pay more for lower quality.

The average increase following the setting of prices between companies is estimated to reach $10 \%$ of the selling price and the corresponding reduction of production to reach $20 \%$. In some recent cases, it has been shown that cartel participants have raised prices from $30 \%$ to $50 \%$.

A number of British authors insist that hard core cartel agreements are in themselves infringements of competition law. This means that there is no need to investigate their pro- or anti-competitive effects and that no market analysis is required. The same idea derives from the judgment of the US Supreme Court in 1958 in the Northern Pacific case, in which the Court admitted that "there are certain agreements or practices which, due to their harmful effect on the competition and lack of any virtue, are rightfully considered unreasonable, and therefore illegal, without the need for a thorough investigation into the exact damage they cau- sed ... And the European courts are gradually moving towards a per se ban on cartels. However, as far as we can see, the jurisprudence still contains certain contradictions.

\section{Analysis of American doctrine related to anticompetitive agreements}

According to some representatives of the American doctrine, the cartels do not necessarily represent the opposite of liberalism and competition, but a variation of them. Because regardless of whether they contributed to the development or to the inhibition of economic progress, they shaped the economic and business history starting with the end of the $19^{\text {th }}$ century. Finally, business historians have demonstrated the various effects and services offered by cartels, such as quality standards, technology transfers, or management risks that have extended beyond the conspiracy motivation to raise prices. Moreover, arguments are made in favor of an interesting point of view, according to which cartels do not contribute to the restriction, limitation or distortion of competition, but to its regularization.

Baker D. examines the criminalization of cartels in Europe, from the perspective of an American practitioner who believes that US efforts to use criminal law as a mechanism to punish conspirators and discourage future participants in cartel-type agreements have been quite successful. This author examines the premises of such an approach within the European Union, sets out the advantages of the investigation process, and indicates alternatives to implementation.

According to Levenstein M., from 1992 to 2010, there were approximately 700 convictions issued by the US Department of Justice for cartels, or over 36 convictions for carteltype agreements per year. It is important to note that, in most cases, a cartel results in more than one conviction, so that this average of raw data from contemporary US cases is not comparable to those in previous studies. 


\section{The Russian academics' overview on cartel agreements}

According to Venedictov A. V. (Венедиктов A.B.), for the specialized academic literature of the Russian Federation, traditionally, the central problem is the classification of some types of entrepreneurial unions and the provisions on cartel legislation. In this sense, a special interest is the monographs of Professor Kaminka A.I. (Каминка А.И.), which analyzed issues related to horizontal anti-competitive agreements at the beginning of the last century and the article by Prof. Sinaiskii V.I. (Синайский B.И.). Also, some important considerations regarding the trade unions and trusts in the Russian Federation were brought by professors Şerşenevici G.F. (Шершеневич Г.Ф.) and Fyodorov A.F. (Федоров А.Ф.). The indicated sources represent the first attempts of the Russian authors in the field of cartel law. It should be noted that the German literature has significantly influenced the work of these authors.

Thus, Kaminka A.I. (Каминка А.И.) defines the notion of "cartel" as a "union of entrepreneurs with the aim of increasing prices or preventing their decrease, either by absolute exclusion or by limiting competition". It should be noted that this definition includes not only cartels, but also other forms of trade unions.

Profe. Sinaiskii V.I. (Синайский В.И.), provides the following definition of the agreement - "agreement between entrepreneurs that aims to eliminate or reduce competition in the process of production or sale of certain types of products."

Folster S. and Peltzman S. examined the data for cartels registered in Sweden and found that: "around the year of 1990, there were over a thousand registered cartel agreements, which affected about 15 percent of total sales of goods and services."

\section{Conclusions}

After studying the works of the above-mentioned academics, we concluded that few au- thors in the Republic of Moldova address the in-force competition regulations, following the adoption of Law 183 of 2012. We found that there is no clarity regarding the definition of the cartel, the difference between common and hard-core cartels. Moreover, in the theoretical sources, there is no systematization of the classification of cartels. In the Republic of Moldova, the field of leniency policy, its application by the Competition Council, the competences of the Council in investigating the causes of anti-competitive agreements, the application of immunity and the reduction of the amount of the fine were not investigated.

In the light of the above, the current paper aimed at shading light over the generalities of cartel definition and regulation in different states, reaching conclusions useful for both theoreticians and practitioners in the field of competition law.

\section{Bibliographycal references}

1. ARBAULT, F., SAKKERS, E. Cartels. În: Faull J., Nikpay A. The EC law of competition. Oxford: Oxford University Press, 2007. p. 1844.

2. BAKER, D. Trying to use criminal law and incarceration to punish participants and deter cartels raises some broad political and social questions in Europe. In the European Competition Law Annual. Hart Publishing, 2014, p. 41-61.

3. BAUXBAUM, M. Deutches Internationalles Kartellrecht. In: Berkeley Law, 1964. 16 p. http:// scholarship.law.berkeley.edu/cgi/viewcontent.cgi? article $=2980 \&$ context $=$ facpubs

4. BISHOP, S., WALKER, M. The Economics of EC Competition Law: Concepts, Application and Measurement. London: Sweet and Maxwell, 2nd edition, 2002. $832 \mathrm{p}$.

5. BOLOGAN, D. Dreptul concurenţei. Note de curs. Chişinău: T-PAR, 2014. p.164.

6. BULMAGA, O. Măsurile organizatorico-juridice în privinţa entităţilor ce desfăşoară practici anticoncurenţiale. Teză de dr. în drept. Chişinău, 2014. $183 \mathrm{p}$

7. CLARKE, R., MORGAN, E. New Developments in UK and EU Competition Policy. Cheltenham: Edward Elgar, 2006. 320 p. 
8. Codul civil al Republicii Moldova Nr. 1107 din 06.06.2002. In: Monitorul Oficial, 22.06.2002, nr. 82-86 art Nr: 661.

9. Commission Regulation (EC) No 772/2004 of 7 April 2004 on the application of Article 81(3) of the Treaty to categories of technology transfer agreements, 1.05.2004 no. 772/2004. In the Official Journal of the European Union, 27.04.2004, no. 123. https://eur-lex.europa.eu/legal-content/EN/ TXT/?uri=LEGISSUM:126108

10. Communication from the Commission - Guidelines on the applicability of Article 101 of the Treaty on the Functioning of the European Union to horizontal co-operation agreements Text with EEA relevance. In: the Official Journal of the European Union, 14.01.2011, no 11/01. https://eur-lex.europa.eu/legal-content/EN/ TXT/?uri=CELEX:52011XC0114(04)

11. CONNOR, J. Price-Fixing Overcharges: Legal and Economic Evidence. In: Law and Economics. United Kingdom: Elsevier Ltd, 2007, vol. 22. 167 p. http://ageconsearch.umn.edu/ bitstream/19254/1/sp05co03.pdf

12. Decizia Curţii Supreme a SUA Northern Pacific Railway Company and Northwestern Improvement Company v. the United States, 10.03.1958, nr. 356 US 1, 78 S Ct 514.

13. ESTRIN, S., HOLMES, P. Competition and Economic Integration in Europe. Cheltenham: Edward Elgar, 1998. 176 p.

14. EZRACHI, A. EU competition law - an analytical guide to the leading cases. Oxford and Portland, Oregon: Hart Publishing, 2010. 500 p.

15. FALLON, M. Droit materiel general de 1' Union Europeenne. Bruxelles: Academia-Bruylant, 2002, p. 902.

16. FEAR, J. Cartels and Competition: neither markets nor hierarchies. Harvard Business School, 2006, nr. 07-011.33 p http://www.hbs.edu/faculty/ Publication\%20Files/07-011.pdf

17. FIEBIG, A. The German Federal Cartel Office and the application of Competition Law in Reunified Germany. In the Journal of International Law, 1993, vol. 14, nr. 3, p. 373-408. http:// scholarship.law.upenn.edu/cgi/view content. cgi? article $=1531 \&$ context $=$ jil

18. FÖLSTER, S., PELTZMAN, S. Competition, Regulation and the Role of Local Government Policies in Swedish Markets. In: Freeman R., Swedenborg B., Topel R. Reforming the Welfare State: Recovery and Beyond in Sweden. Chicago: The University of Chicago Press, 2010, p. 253-284.
19. GHEORGHIU, G., NIŢA, M. Dreptul concurenţei interne şi europene. Bucureşti: Universul Juridic, 2011, p. 272.

20. Handbook of Competition Enforcement Agencies: German Antitrust Law, 2005, p. 58-60 http://www.gibsondunn.com/fstore/documents/ pubs/2005_hbk_comp_enf-german-walther.pdf

21. IRINE $\bar{S} \bar{C} U$, L. Dreptul concurenţei. Suport de curs. Iaşi: Universitatea „Al. I. Cuza”, 20122013, p.81. https://www.academia.edu/3723579/ Dreptul_Concurentei

22. Legea Republicii Moldova cu privire la protecţia concurenţei nr. 1103-XIV din 30.06.2000. În: Monitorul Oficial al Republicii Moldova, 31.12.2000, nr. 166-168. Abrogată.

23. LEVENSTEIN, M., SUSLOW, V. Cartels and Collusion. In: Oxford Handbook on International Antitrust Economics, 2012. 32 p.

24. MĂRGINEANU, G., MĂRGINEANU, L. Dreptul afacerilor. Chişinău: Elena - V.I. 2004. p. 721 .

25. MOTTA, M. Competition Policy: Theory and Practice. Cambridge: Cambridge University Press, 2005. 642 p.

26. PETERS, L.L. Managing Competition in German Coal, 1893-1913. In the Journal of Economic History, 1989, nr. 49/2, p. 419-433.

27. PRESCURE, T. Curs de dreptul concurenţei comerciale. Bucureşti: Rosetti, 2004, p. 177.

28. Regulamentul (CE) nr.772/2004 al Comisiei privind aplicarea articolului 81 alineatul (3) din tratat anumitor categorii de acorduri de transfer de tehnologie, 1.05.2004 nr. 772/2004. În: Jurnalul Oficial al Uniunii Europene, 27.04.2004, nr. 123. http://eur-lex.europa.eu/legal-content/RO/ TXT/?uri=URISERV\%3A126108

29. ROŞCA, N., BAIEş, S. Dreptul afacerilor, Chişinău: Tipografia Centrală, 2011, 576 p.

30. RUSU, V., FOCŞA, G. Curs de drept comercial. Chișinău: Academia de Studii Economice din Moldova, 2006. p. 493.

31. STEPHAN, A. Cartels. In: Handbook on European Competition Law, 2013, p.216-241.

32. STUART, E., MATEUS, A. Legislaţia şi politica în domeniul concurenţei. Chişinău: Sinectica-Com, 2010, 152 p.

33. Legea concurenţei a României nr. 21/1996. In: Monitorul Oficial al României, 22.04.2004, nr. 430 .

34. SYMEONIDIs, G. Are cartel laws bad for business? Evidence from the UK. University of Essex, 2000. p. 1-46. https://www.essex.ac.uk/ 
economics/discussion-papers/papers-text/dp511. pdf

35. The Antitrust Revolution in Europe, Exploring the European Commission's Cartel Policy. Cheltenham, UK: Lee McGowan, Edward Elgar, 2010. 228 p.

36. TSCHIERSCHKY, S. Cartel and Trust. A comparative study of their nature and significance. Göttingen. In the Journal of Economics and Statistics, 1904, vol. 27 (82). nr. 6. p. 837-842.

37. VOLCINSCHI, V., COJOCARI, E. Drept economic. Chişinău: USM, 2006. 426 p.

38. WHISH, R. Competition Law. Oxford: Oxford University Press, 2009. 1006 p.

39. ВЕНЕДИКТОВ, А.В., Науч. ред.: Иванов А.А.: Избранные труды по гражданскому праву. В 2-х томах. Т. 1, Издательство: Статут. Москва, 2004. 463 с.

40. КАМИНКа, А.И. Предпринимательские союзы. Очерки картельного права. Тип. т-ва Обществ. польза, 1909, 183 с.

41. КАМИНКа, А.И. Предпринимательские союзы. Очерки картельного права. Тип. т-ва Обществ. польза, 1909, 183 с.

42. СИНАЙСКИЙ, В.И. Договор предпринимательского союза (синдиката и треста). Сборник статей по гражданскому и торговому праву. Памяти профессора Габриэля Феликсовича Шершеневича. Статут, 2005, с. $56-70$.

43. СИНАЙСКИЙ, В.И. Договор предпринимательского союза (синдиката и треста). Сборник статей по гражданскому и торговому праву. Памяти профессора Габриэля Феликсовича Шершеневича. Статут, 2005 , с. $56-70$.

44. ФЕДОРОВ, А.Ф. Торговое право. Одесса: Славянская, 1911, 896 с.

45. ШЕРШЕНЕВИЧ, Г.Ф. Курс торгового права. Статут, 2003, т. I, 480 c. 